\title{
Вплив різних моделей іммобілізаційного стресу на функціональні зміни в серці високо- і низькостійких до гострої гіпоксичної гіпоксії щурів різної статі
}

\begin{abstract}
Мета роботи: визначити вплив різних моделей іммобілізаційного стресу на зміни показників електрокардіограми (ЕКГ) у самців і самиць щурів з високою і низькою стійкістю до гіпоксії (ВГ, НГ).

Матеріали і методи. У дослід взяли 135 щурі. Тварин поділено на три групи - контрольну та дві дослідні (які зазнали іммобілізаційного стресу). Стрес моделювали 4 рази одногодинною м’якою іммобілізацією щурів спинкою донизу з інтервалом 24 години (стрес 1) і 72 години (стрес 2). Дослідження проводили через 24 години після останньої іммобілізації. У всіх піддослідних тварин під наркозом реєстрували ЕКГ.

Результати досліджень та їх обговорення. При аналізі показників ЕКГ у щурів спостерігали незначні зміни тривалості та амплітуди зубців та інтервалів. Так, при порівнянні груп контрольних ВГ і НГ самців достовірних показників на ЕКГ не виявлено. Аналогічно не було достовірної різниці між досліджуваними ЕКГ показниками у ВГ і НГ самиць. Стрес 1 призвів до зниження відхилення сегмента ST від ізолінії порівняно з контрольними значеннями у ВГ самців і у ВГ самиць. У НГ самиць зросла ЧСС, зменшилися тривалість інтервалу RR та показник QTс. У ВГ самців, порівняно з ВГ самицями, була менша амплітуда зубця R. Стрес 2, порівняно з контролем, у ВГ самців спричинив підвищення амплітуди зубця R. У ВГ самців, порівняно з НГ, спостерігали більше відхилення сегмента ST від ізолінії; у НГ самиць зросла ЧСС, зменшилися тривалість інтервалу RR, тривалість та амплітуда зубця P, тривалість інтервалу QT та QTс. У ВГ самиць, порівняно з НГ, була більша тривалість інтервалу QT. Після стресу 2 встановили, що у ВГ самців, порівняно з самицями, були більшими амплітуда зубця R і відхилення сегмента ST від ізолінії. У НГ самців, порівняно з НГ самицями, була більшою тривалість інтервалу QT.
\end{abstract}

Ключові слова: іммобілізаційний стрес; щури; резистентність до гіпоксії; ЕКГ.

Постановка проблеми і аналіз останніх досліджень та публікацій. Реактивність організму залежить від типу вищої нервової діяльності [1], регуляторних впливів із боку автономної нервової [2], ендокринної [3] та імунної систем [4], статі [5], віку [6], умов навколишнього середовища [7] тощо. Одним із факторів, при якому змінюється реактивність, є стрес. Стрес повсякденного життя може повторюватися з певною періодичністю, причому він може бути як очікуваним, так і несподіваним. Механізми реагування на стрес $є$ універсальними, а переважання ураження чи захисту залежать від індивідуальної реактивності організму [8].

Основним у розвитку більшості пошкоджень $є$ відповідь організму на гіпоксію. Вона є центральною ознакою багатьох широко поширених захворювань людини, включно ішемічну хворобу серця, інсульт, анемію, хронічне обструктивне захворювання легень, легеневу гіпертензію тощо [9]. У загальній популяції кожного біологічного виду тварин є особини з різною стійкістю до нестачі кисню [8]. Вивчення механізмів, які забезпечують такі особливості функціонування у живих істот, може бути базовим для розробки методів профілактики і лікування.

Мета роботи: визначити вплив різних моделей іммобілізаційного стресу на зміни показників ЕКГ у самців і самиць щурів з високою і низькою стійкістю до гіпоксії.
Матеріали і методи. Досліди виконано на 135 високо- і низькостійких до гіпоксії (ВГ і НГ) щурах віком 5,5-6 місяців. Тварин поділено на три групи - контрольну та дві дослідні (тих, які зазнали іммобілізаційного стресу). Виділення із загальної когорти тварин особин з різною стійкістю до гіпоксії проводили за методикою В. Я. Березовського (1978) [10]. Різні моделі стресу моделювали шляхом чотириразової одногодинної іммобілізації щурів спинкою донизу з інтервалом у 24 години (стрес 1) і 72 години (стрес 2) між окремими стресовими епізодами. Дослідження проводили через 24 години після останньої іммобілізації [11].

Усі експерименти проводили в першій половині дня в спеціально відведеному приміщенні при температурі 18-22 ${ }^{\circ} \mathrm{C}$, відносній вологості 4060 \% і освітленості 250 лк. Досліди виконано з дотриманням норм Конвенції Ради Європи про захист хребетних тварин, що використовуються для досліджень та інших наукових цілей (Страсбург, 18.03.1986р.), ухвали Першого національного конгресу з біоетики (Київ, 2001) і наказу МОЗ України від 23.09.2009 р. № 690.

Для визначення ступеня порушення функціонального стану кардіоміоцитів за допомогою пристрою “Кардіолаб” (Харків, Україна) реєстрували електрокардіограми (ЕКГ) з комп’ютерним аналізом тривалості інтервалів, зубців та їх ампліту- 
ди. Записи ЕКГ у тварин проводили під тіопенталнатрієвим наркозом (40 мг·кг-1 маси тіла тварини внутрішньочеревно).

Статистичну обробку цифрових даних виконано за допомогою програмного забезпечення “Excel” ("Microsoft”, CША) та "STATISTICA" 6.0 ("Statsoft”, США). Достовірність різниці значень між незалежними кількісними величинами ви- значали при нормальному розподілі за критерієм Стьюдента, в інших випадках - за допомогою непараметричних методів.

Результати досліджень та їх обговорення. При аналізі показників ЕКГ у щурів спостерігали незначні зміни тривалості та амплітуди зубців та інтервалів (табл.). При порівнянні груп конт-

Таблиця. Зміни на електрокардіограмах, зумовлені стресом, у високо- і низькостійких до гіпоксії щурів

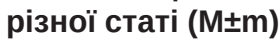

\begin{tabular}{|c|c|c|c|c|}
\hline \multirow{3}{*}{ Показник } & \multicolumn{4}{|c|}{ Група } \\
\hline & \multicolumn{2}{|c|}{ самці } & \multicolumn{2}{|c|}{ самиці } \\
\hline & $\mathrm{B} \Gamma$ & НГ & $\mathrm{B} \Gamma$ & НГ \\
\hline \multicolumn{5}{|c|}{ Контроль } \\
\hline & $\mathrm{n}=12$ & $\mathrm{n}=12$ & $\mathrm{n}=10$ & $\mathrm{n}=11$ \\
\hline ЧСС, $\mathrm{xB}^{-1}$ & $453,92 \pm 10,98$ & $424,25 \pm 10,83$ & $421,00 \pm 6,06^{\#}$ & $394,36 \pm 15,73$ \\
\hline RR, MC & $133,00 \pm 3,47$ & $142,25 \pm 3,47$ & $142,80 \pm 2,00^{\#}$ & $154,36 \pm 6,64$ \\
\hline $\mathrm{P}, \mathrm{MC}$ & $11,67 \pm 1,00$ & $12,00 \pm 1,39$ & $14,80 \pm 2,27$ & $14,73 \pm 1,17$ \\
\hline P, мB & $0,116 \pm 0,025$ & $0,110 \pm 0,017$ & $0,104 \pm 0,022$ & $0,149 \pm 0,022$ \\
\hline $\mathrm{R}, \mathrm{mB}$ & $0,614 \pm 0,065$ & $0,705 \pm 0,051$ & $0,565 \pm 0,086$ & $0,635 \pm 0,073$ \\
\hline QT, Mc & $76,00 \pm 4,52$ & $74,00 \pm 4,66$ & $85,20 \pm 3,74$ & $90,00 \pm 5,71$ \\
\hline QTc, Mc & $145,83 \pm 1,86$ & $151,00 \pm 1,82$ & $151,30 \pm 1,06^{\#}$ & $156,82 \pm 3,30$ \\
\hline $\mathrm{ST}, \mathrm{MB}$ & $0,088 \pm 0,018$ & $0,075 \pm 0,039$ & $-0,048 \pm 0,036^{\#}$ & $-0,015 \pm 0,039$ \\
\hline \multicolumn{5}{|c|}{ Стрес 1} \\
\hline & $\mathrm{n}=10$ & $\mathrm{n}=12$ & $\mathrm{n}=12$ & $\mathrm{n}=12$ \\
\hline ЧСС, $\mathrm{xB}^{-1}$ & $438,89 \pm 8,93$ & $458,75 \pm 12,89$ & $416,18 \pm 17,17$ & $456,30 \pm 12,56^{*}$ \\
\hline $\mathrm{RR}, \mathrm{MC}$ & $137,33 \pm 2,86$ & $131,83 \pm 3,59$ & $146,36 \pm 5,86$ & $132,40 \pm 3,81^{*}$ \\
\hline P, MC & $13,33 \pm 1,51$ & $12,00 \pm 2,89$ & $9,64 \pm 1,01$ & $11,20 \pm 0,95$ \\
\hline P, мB & $0,119 \pm 0,010$ & $0,057 \pm 0,028$ & $0,091 \pm 0,012$ & $0,100 \pm 0,010$ \\
\hline $\mathrm{R}, \mathrm{MB}$ & $0,588 \pm 0,050$ & $0,586 \pm 0,074$ & $0,754 \pm 0,028^{\#}$ & $0,730 \pm 0,113$ \\
\hline QT, MC & $86,00 \pm 3,93$ & $74,42 \pm 3,97$ & $84,45 \pm 2,60$ & $80,40 \pm 2,77$ \\
\hline QTc, Mc & $148,11 \pm 1,56$ & $145,33 \pm 1,98$ & $152,91 \pm 3,04$ & $145,50 \pm 2,04^{*}$ \\
\hline $\mathrm{ST}, \mathrm{MB}$ & $0,030 \pm 0,016^{*}$ & $0,113 \pm 0,042$ & $0,070 \pm 0,015^{*}$ & $0,039 \pm 0,017$ \\
\hline \multicolumn{5}{|c|}{ Стрес 2} \\
\hline & $\mathrm{n}=12$ & $\mathrm{n}=12$ & $\mathrm{n}=10$ & $\mathrm{n}=10$ \\
\hline ЧСС, $\mathrm{xB}^{-1}$ & $435,50 \pm 12,92$ & $424,58 \pm 11,71$ & $432,40 \pm 7,82$ & $467,20 \pm 16,58^{*}$ \\
\hline $\mathrm{RR}, \mathrm{MC}$ & $139,00 \pm 4,24$ & $142,33 \pm 4,18$ & $139,20 \pm 2,52$ & $129,80 \pm 4,78^{*}$ \\
\hline P, MC & $11,17 \pm 1,00$ & $12,33 \pm 1,23$ & $13,60 \pm 1,02^{\&}$ & $9,40 \pm 0,89^{*, * *}$ \\
\hline $\mathrm{P}, \mathrm{MB}$ & $0,103 \pm 0,008$ & $0,105 \pm 0,007$ & $0,104 \pm 0,010$ & $0,079 \pm 0,012^{*}$ \\
\hline $\mathrm{R}, \mathrm{MB}$ & $0,822 \pm 0,054^{*}, \&$ & $0,748 \pm 0,051$ & $0,587 \pm 0,059^{\#, \&}$ & $0,667 \pm 0,042$ \\
\hline QT, мс & $77,83 \pm 2,97$ & $83,33 \pm 3,69$ & $89,40 \pm 4,36$ & $66,60 \pm 4,80^{*, * *, \#, \&}$ \\
\hline QTс, Mc & $148,92 \pm 2,27$ & $150,75 \pm 2,21$ & $149,30 \pm 1,37$ & $144,00 \pm 2,97^{*}$ \\
\hline $\mathrm{ST}, \mathrm{MB}$ & $0,064 \pm 0,012$ & $0,022 \pm 0,010^{* *}$ & $-0,010 \pm 0,017^{\#, \&}$ & $-0,002 \pm 0,016$ \\
\hline
\end{tabular}

Примітки: 1. * - показники достовірні, порівняно з контролем;

2. ** - показники достовірні, порівняно з ВГ;

3. \# - показники достовірні, порівняно з самцями відповідної групи;

4. \& - показники достовірні, порівняно з стресом 1. 
рольних ВГ і НГ самців достовірних показників на ЕКГ не виявлено. Аналогічно не було достовірної різниці між досліджуваними ЕКГ показниками у ВГ і НГ самиць. Встановлено різницю у показниках між ВГ самцями і самицями. Так, у самиць, порівняно з самцями, частота серцевих скорочень (ЧСС) була меншою на 7,25 \% (p<0,02), тривалість інтервалу RR більшою на 7,37 \% ( $<<0,05)$, показник QTс був більшим на 3,75 \% ( $<0,02)$, а відхилення сегмента ST відносно ізолінії було на $54,34 \%(\mathrm{p}<0,002)$ меншим.

Отже, на ЕКГ у контролі не встановлено достовірної різниці показників між ВГ і НГ тваринами різної статі. У самців була більша ЧСС, що зумовлено більшими адренергічними впливами на серце.

Стрес 1 призвів до зниження відхилення сегмента ST від ізолінії порівняно з контрольними значеннями у ВГ самців на $66,04 \%(\mathrm{p}<0,05)$, у ВГ самиць - у 2,46 раза $(\mathrm{p}<0,02)$. У НГ самиць зросла на 15,7 \% $(\mathrm{p}<0,01)$ ЧСС, зменшилися на 14,23 $\%(\mathrm{p}<0,02)$ тривалість інтервалу RR та на 7,22 \% ( $<0,02)$ - показник QТс. У ВГ самців, порівняно з ВГ самицями, встановлено на 28,37 \% ( $<<0,01)$ меншу амплітуду зубця R.

Підняття сегмента ST відносно ізолінії, яке було після стресу тільки у ВГ тварин, можна пов’язати з гіпоксією міокарда, підвищеним тромбоутворенням. У НГ самиць після стресу 1 встановлено збільшення збудливості сино-атріального вузла. Очевидно, що це пов'язано з активацією не тільки симпато-адреналової, але й гіпоталамогіпофізарно-наднирниковозалозної системи, і може бути розцінене як хронічний стрес. Зменшення ж у НГ самиць інтервалу QTс може вказувати на зменшене виділення естрогенів, які мають кардіопротекторний вплив.

Стрес 2, порівняно з контролем, у ВГ самців спричинив підвищення на 33,92 \% $(\mathrm{p}<0,01)$ амплітуди зубця R. У ВГ самців, порівняно з НГ, відмічено більше на 66,23 \% $(\mathrm{p}<0,02)$ відхилення сегмента ST від ізолінії. Після стресу 2 у ВГ самиць не встановлено жодних показників порівняно з контролем. У НГ самиць під впливом цієї моделі стресу, порівняно з контролем, зросла на 18,47 \% (p<0,01) ЧСС, зменшилися на 15,91 \% ( $<0,01)$, тривалість інтервалу RR, на 36,17 \% ( $<0,002)$ - тривалість та на 47,01 \% (p<0,02) амплітуда зубця P, на 26,00 \% $(\mathrm{p}<0,01)$ - тривалість інтервалу QT та на 8,172 \% $(\mathrm{p}<0,01)$ - показник QTс. У ВГ самиць, порівняно з НГ, була більша на 25,5 \% $(\mathrm{p}<0,002)$ тривалість інтервалу QT. Після стресу 2 виявилося, що у ВГ самців, порівняно з ВГ самицями, були більшими на 28,37 \% (p<0,01) амплітуда зубця R i на 15,58 \% $(\mathrm{p}<0,002)$ - відхилення сегмента ST від ізолінії. У НГ самців, порівняно з НГ самицями, була більшою на 20,08 \% $(\mathrm{p}<0,02)$ тривалість інтервалу QT. Отже, стрес, який повторювався кожні 72 години, у ВГ самців викликав зростання проведення імпульсів шлуночками, у НГ самиць - до порушення процесів автоматизму, збудливості, провідності передсердями та шлуночками.

При аналізі показників ЕКГ при двох моделях іммобілізаційного стресу встановлено наступне. При іммобілізаційному стресі, що повторювався кожні 24 години, порівняно із стресом, який повторювався кожні 72 години, у ВГ самців була меншою на 28,54 \% (p<0,002) амплітуда зубця R. У ВГ самиць при стресі 1, порівняно із стресом 2, була меншою на 29,14 \% $(\mathrm{p}<0,02)$ тривалість зубця $\mathrm{P}$, більшою на $28,54 \%(\mathrm{p}<0,02)$ амплітуда зубця $\mathrm{R}, \mathrm{y} 7$ разів $(\mathrm{p}<0,002)$ було більшим відхилення сегмента ST. У НГ самиць при стресі 1, порівняно із стресом 2, виявилися на 20,72 \% $(\mathrm{p}<0,05)$ більшою тривалість інтервалу QT.

Отримані дані можна розцінювати наступним чином. У ВГ самців при стресі 2, порівняно із стресом 1, більше проведення імпульсів шлуночками, а у ВГ самиць при стресі 1 , порівняно із стресом 2, було швидшим проходження імпульсів передсердями та шлуночками і відхилення сегмента ST (показник також зростає порівняно з контролем), що можна розцінювати як більшу гіпоксію. У НГ самиць при стресі 1 , порівняно із стресом 2 , виявилося сповільнення проходження імпульсів шлуночками, що може вказувати на менше ураження міокарда при стресі 1.

Висновки. Інтервальна іммобілізація щурів призводить до порушень процесів автоматизму, збудливості та провідності тільки у НГ самиць. У НГ самців не відмічено змін на ЕКГ. У ВГ самців і самиць при стресі 1 виникає, відповідно, дистрофія і гіпоксія міокарда, а при стресі 2 у самців зростає деполяризація шлуночків.

Перспективи подальших досліджень. Для встановлення механізмів кардіопротекторної дії буде проведено аналіз вегетативного забезпечення серцевого ритму та морфологічне дослідження серця і надниркових залоз. 


\section{СПИСОК ЛІТЕРАТУРИ}

1. Typological features of the nervous system of cows depending on the reactivity and stress resistance / L. V. Karlova, O. G. Gavrilina, N. V. Alekseeva, O. V. Peretyatko // Ukrainian Journal of Ecology. - 2018. - Vol. 8 (2). - P. 149-159.

2. Autonomic nervous system reactivity to positive and negative mood induction: The role of acute psychological responses and frontal electrocortical activity / W. J. Kop, S. J. Synowski, M. E. Newell [et al.] // Biol. Psychol. - 2011. - Vol. 86 (3). P. 230-238.

3. Testosterone-cortisol dissociation in children exposed to prenatal maternal stress, and relationship with aggression: Project Ice Storm / T. V. Nguyen, S. L. Jones, G. Elgbeili [et al.] // Dev. Psychopathol. - 2018. - Vol. 30 (3). -P. 981-994.

4. Дорубець А. Д. Загальна імунологічна реактивність організму пацієнтів з малими дефектами зубних рядів / А. Д. Дорубець // Клінічна та експериментальна патологія. - 2016. Vol. 55 (1). - C. 59-62.

5. Children's stress regulation mediates the association between prenatal maternal mood and child executive functions for boys, but not girls / R. Neuenschwander, K. Hookenson, U. Brain [et al.] // Dev. Psychopathol. - 2018. - Vol. 30 (3). - P. 953-969. 6 . Influence of age, sex and seriousness on reporting of adverse drug reactions in Sweden / L. Holm, E. Ekman, K. J. Blomgren //

\section{REFERENCES}

1. Karlova, L.V., Gavrilina, O.G., Alekseeva, N.V., \& Peretyatko, O.V. (2018). Typological features of the nervous system of cows depending on the reactivity and stress resistance. Ukrainian Journal of Ecology, 8 (2), 149-159.

2. Kop, W.J., Synowski, S.J., Newell, M.E., Schmidt, L.A., Waldstein, S.R., \& Fox, N.A. (2011). Autonomic nervous system reactivity to positive and negative mood induction: The role of acute psychological responses and frontal electrocortical activity. Biol. Psychol., 86 (3), 230-238.

3. Nguyen, T.V., Jones, S.L., Elgbeili, G., Monnier, P., Yu, C., Laplante, D.P., \& King, S. (2018). Testosterone-cortisol dissociation in children exposed to prenatal maternal stress, and relationship with aggression: Project Ice Storm. Dev. Psychopathol., 30 (3), 981-994.

4. Dorubets, A.D. (2016). Zahalna imunolohichna reaktyvnist orhanizmu patsiientiv z malymy defektamy zubnykh riadiv [General immunological reactivity of the body of patients with small defects in dentition]. Klinichna ta eksperymentalna patolohiia - Clinical and Experimental Pathology, 55 (1), 59-62 [in Ukrainian].

5. Neuenschwander, R., Hookenson, K., Brain, U., Grunau, R.E., Devlin, A.M., Weinberg, J., Diamond, A., Oberlander, T.F. (2018) Children's stress regulation mediates the association between prenatal maternal mood and child executive functions for boys, but not girls. Dev. Psychopathol., 30 (3), 953-969.

6. Holm, L., Ekman, E., \& Jorsäter Blomgren K. (2017). Influence of age, sex and seriousness on reporting of adverse drug reactions in Sweden. Pharmacoepidemiol. Drug Saf., 26 (3), 335-343.
Pharmacoepidemiol. Drug Saf. - 2017. - Vol. 26 (3). - P. 335-343. 7. Children's Autonomic Nervous System Reactivity Moderates the Relations between Family Adversity and Sleep Problems in Latino 5-Year Olds in the CHAMACOS Study / A. Alkon, W. T. Boyce, T. B. Neilands, B. Eskenazi // Front. Public Health. - 2017. - Vol. 5. - P. 155.

8. Пшенникова М. Г. Роль генетических особенностей организма в устойчивости к повреждающим воздействиям и в защитных эффектах адаптации / М. Г. Пшенникова // Патологическая физиология и экспериментальная терапия. -2011. - № 4. - С. 7-16.

9. Зарубина И. В. Современные представдения о патогенезе гипоксии и её фармакологической коррекции / И. В. Зарубина // Обзоры по клинической фармакологии и лекарственной терапии. - 2011. - 8(3). - С. 31-48.

10. Березовский В. А. Гипоксия и индивидуальные особенности реактивности / В. А. Березовский. - К. : Наукова думка, 1978. - 216 с.

11. Кулинский В. И. Две адаптационные стратегии в неблагоприятных условиях: резистентная и толерантная. Роль гормонов и рецепторов / В. И. Кулинский, И. А. Ольховский // Успехи современной биологии. - 1992. - 112. С. 697-711.

7. Alkon, A., Boyce, W.T., Neilands, T.B., \& Eskenazi, B. (2017). Children's Autonomic Nervous System Reactivity Moderates the Relations between Family Adversity and Sleep Problems in Latino 5-Year Olds in the CHAMACOS Study. Front Public Health, 5, 155.

8. Pshennikova, M.G. (2011) Rol geneticheskikh osobennostey organisma v ustoychivosti k povrezhdayushchim vozdeystviyam i v zashchitnykh effektakh adaptatsii [The role of genetic features of the organism in resistance to damaging effects and protective effects of adaptation]. Patologicheskaya phisiologiya i eksperimentalnaya terapiya - Pathological Physiology and Experimental Therapy, 4, 7-16 [in Russian].

9. Zarubina, I.V. (2011). Sovremennye predstavleniya o patogeneze gipoxii i ego farmakolgicheskoy korrektsii [Contemporary notions about the pathogenesis of hypoxia and its pharmacological correction]. Obzory po klinicheskoy farmakologii i lekarstvennou terapii - Reviews on Clinical Pharmacology and Drug Therapy, 8 (3), 31-48 [in Russian].

10. Berezovskyy, V.A. (1978). Gipoksiya i individualnye osobennosti reaktivnosti [Hypoxia and individual particularities of reactivity]. Kyiv: Naukova dumka [in Russian].

11. Kulynskyy, V.I., \& Olkhovskyy, I.A. (1992). Dve adaptatsionnye strategii v neblagopriyatnykh usloviyakh: rezistentnaya i tolerantnaya. Rol gormonov i retseptorov [Two adaptation strategies in adverse conditions: resistant and tolerant. The role of hormones and receptors]. Uspekhi sovremennoy biologii - Advances of Modern Biology, 112, 697-711 [in Russian]. 
O. V. DENEFIL, IU. M. ORDYNSKYI

I. Horbachevsky Ternopil State Medical University

\title{
THE INFLUENCE OF DIFFERENT MODELS OF IMMOBILIZATION STRESS ON FUNCTIONAL CHANGES IN THE HEART OF HIGH- AND LOW-RESISTANCE TO ACUTE HYPOXIC HYPOXIA RATS OF DIFFERENT SEX
}

\begin{abstract}
The aim of the work: to determine the effect of different models of immobilization stress on changes in electrocardiogram (ECG) in male and female rats with high and low resistance to hypoxia (HR, LR).

Materials and Methods. 135 rats were taken into the experiment. Animals were divided into three groups - control and two experimental (which experienced immobilization stress). Stress was modeled 4 times by one-hour mild immobilization of rats with the back down, at intervals of 24 hours (stress 1 ) and 72 hours (stress 2). The studies were performed 24 hours after the last immobilization. In all experimental animals ECG was recorded.

Results and Discussion. In the analysis of ECG indices in rats, slight changes in the duration and amplitude of the waves and intervals were noted. Thus, when comparing groups of control LR and HR males did not show reliable indicators on the ECG. Similarly, there was no significant difference between the ECGs studied in the HR and LR female rats. Stress 1 resulted to decrease in the deviation of the ST segment from the isoline compared with controls HR male rats and HR female rats. In LR female rats the heart rate increased, the duration of the RR interval and the QTc were decreased. The HR male rats compare to HR female rats, had smaller R wave amplitude. Stress 2, compared to the control, leads to increase the R wave amplitude in the HR male rats. In HR female rat, comparing to LR, the deviation of the ST segment from the isoline was higher; in LR female rats the heart rate increased, the duration of the RR interval, the duration and amplitude of the P wave, the duration of the QT and QTc interval were decreased. In HR female rats, compared to LR female rats was a longer QT interval. After stress 2, it was found that the HR male rats, compared to females, had a larger amplitude of the R wave and deviation of the ST segment from the isoline. LR male rats had a longer QT interval compared to LR female rats.
\end{abstract}

Key words: immobilization stress; rats; resistance to hypoxia; ECG.

\section{О. В. ДЕНЕФИЛЬ, Ю. М. ОРДЫНСКИЙ}

гВУЗ “Тернопольский государственный медицинский университет имени И. Я. Горбачевского МОЗ Украины”

\section{ВЛИЯНИЕ РАЗЛИЧНЫХ МОДЕЛЕЙ ИММОБИЛИЗАЦИОННОГО СТРЕССА НА ФУНКЦИОНАЛЬНЫЕ ИЗМЕНЕНИЯ В СЕРДЦЕ ВЫСОКО- И НИЗКОУСТОЙЧИВЫХ К ОСТРОЙ ГИПОКСИЧЕСКОЙ ГИПОКСИИ КРЫС РАЗНОГО ПОЛА}

\begin{abstract}
Цель работы: определить влияние различных моделей иммобилизационного стресса на изменения показателей электрокардиограммы (ЭКГ) у самцов и самок крыс с высокой и низкой устойчивостью к гипоксии (ВГ, НГ).

Материалы и методы. В опыт взяли 135 крыс. Животных разделили на три группы - контрольную и две опытных (подвергшихся иммобилизационному стрессу). Стресс моделировали 4 раза одночасовой мягкой иммобилизацией крыс спинкой книзу с интервалом между иммобилизацией 24 часа (стресс 1) и 72 часа (стресс 2). Исследование проводили через 24 часа после последней иммобилизации. Во всех подопытных животных под наркозом регистрировали ЭКГ.

Результаты исследований и их обсуждение. При анализе показателей ЭКГ у крыс отмечено незначительные изменения продолжительности и амплитуды зубцов и интервалов. Так, при сравнении групп контрольных ВГ и НГ самцов достоверных показателей на ЭКГ не обнаружено. Аналогично не было достоверной разницы между исследуемыми ЭКГ показателями у ВГ и НГ самок. Стресс 1 привел к снижению отклонения сегмента ST от изолинии по сравнению с контрольными значениями у ВГ самцов и самок. У НГ самок увеличилась ЧСС, уменьшились продолжительность интервала RR и показатель QTс. У ВГ самцов, по сравнению с ВГ самками, была меньше амплитуда зубца R. Стресс 2 по сравнению с контролем, у ВГ самцов вызвал повышение амплитуды зубца R. В ВГ самцов, по сравнению с НГ, отмечено большее отклонение сегмента ST от изолинии; у HГ самок увеличилась ЧСC, уменьшились продолжительность интервала RR, продолжительность и амплитуда зубца P, продолжительность интервала QT и QTс. У ВГ самок по сравнению с НГ, была большая продолжительность интервала QT. После стресса 2 оказалось, что у ВГ самцов, по сравнению с самками, были большими амплитуда зубца R и отклонение сегмента ST от изолинии. У НГ самцов, по сравнению с НГ самками, была больше продолжительность интервала QT.
\end{abstract}

Ключевые слова: иммобилизационный стресс; крысы; резистентность к гипоксии; ЭКГ. 